\title{
MANAJEMEN KARIR: PERMASALAHAN MOBILITAS DAN PENGEMBANGAN KARIR INDIVIDU DALAM ORGANISASI
}

\author{
Theresia Diah Widiastuti \\ Universitas Atma Jaya Yogyakarta
}

\begin{abstract}
This paper explores in depth some problems and issues related to individual career mobility at work place and the role of organization in employee career development activities at work place. The exploration will be developed further by making advanced analysis on career management, especially the importance of career planning and development and also some obstacles for career mobility seen from an individual and organizational perspective. This paper also identifies some factors that facilitate individual career mobility process and a number of career development intervention activities in an organization.
\end{abstract}

Keywords: career mobility, career management, career development intervention

\section{PENDAHULUAN}

Aneka perubahan yang terjadi ditempat kerja ditandai dengan semakin lebarnya kesenjangan antara kemampuan yang dituntut organisasi dengan kemampuan yang dimiliki karyawan, kurangnya kesempatan pengembangan karir, semakin hilangnya kebanggaan kerja dan keamanan di tempat kerja, telah banyak mempengaruhi kebijakan pengelolaan sumberdaya manusia organisasi, termasuk didalamnya aktivitas perencanaan dan pengelolaan karir. Berbagai perubahan lingkungan yang berasal dari pergeseran secara terus menerus antar sektor dalam pekerjaan, bentuk perusahaan yang senantiasa berubah dalam proses adaptasi perubahan lingkungan eksternal maupun pengenalan tehnologi baru, merupakan permasalahan perubahan di tempat kerja yang menyita perhatian para pengelola maupun praktisi sumberdaya manusia kaitannya dengan analisis perubahan lingkungan ketenagakerjaan.

Setiap organisasi dituntut untuk mampu mengenali dan memahami sifat perubahan dalam konteks dunia kerja yang selanjutnya bermanfaat guna meninjau ulang implikasinya terhadap kebijakan pengelolaan sumberdaya manusia organisasi. Realisasi pengelolaan karir karyawan secara efektif akan dapat menciptakan konstribusi penting bagi penciptaan competitive advantage organisasi. Berbagai perubahan mendasar dan kompleksitas permasalahan di lingkungan kerja, menuntut adanya penyesuaian beban tugas yang diemban karyawan dengan laju pengembangan karir karyawan secara individu dalam organisasi. Apabila dirasa tidak seimbang atau tidak adil, akan menimbulkan ketidakpuasan karyawan yang selanjutnya mempengaruhi gairah maupun prestasi kerjanya dan dalam jangka panjang akan menyebabkan penurunan produktivitas organisasi secara keseluruhan.

Permasalahan karir dan pengelolaannya secara efektif menjadi penting bagi karyawan itu sendiri maupun pencapaian tujuan organisasi, yang ditunjukkan oleh adanya tuntutan agar sumberdaya manusia organisasi menyediakan bantuan dalam bentuk berbagai intervensi dalam aktivitas pengembangan karir. Berbagai program intervensi pengembangan karir tersebut dibutuhkan karyawan dalam penentuan sasaran dan pengembangan diri, perencanaan tujuan karir dan sasaran karir yang secara bersama-sama akan menciptakan kekuatan pekerja dan bermanfaat bagi organisasi. 


\section{MANAJEMEN KARIR: PERENCANAAN DAN PENGEMBANGAN KARIR}

Pada dasarnya setiap karyawan menginginkan kemajuan dalam hidupnya termasuk kemajuan yang diinginkan selama kehidupan kerjanya di organisasi sebagai tahapan perkembangan dan pertumbuhan karir. Bertitik tolak pada pemikiran seperti maka karyawan yang mengawali karirnya dengan bekerja di organisasi akan memiliki keinginan untuk meniti karir sampai akhirnya memasuki masa tidak produktif atau masa pensiun. Tetapi mobilitas karir setiap individu dalam organisasi adalah unik, dimana satu individu dengan individu yang lain akan memiliki jalur karir, sasaran karir, perencanaan karir dan pengembangan karir yang berbeda. Dimana ada individu yang harus memulai karir dari jenjang pekerjaan terendah untuk sampai pada pencapaian keberhasilan karir, tetapi ada juga individu yang langsung mendapatkan posisi strategis dalam organisasi karena telah mampu memenuhi spesifikasi jabatan di awal karirnya.

Menurut Willesky (1964) seperti yang dikutip oleh Garavan (1996) memberikan pengertian tentang karir dari sudut pandang sosiologi, karir dianggap sebagai suksesi dari sejumlah pekerjaan yang tersedia dalam hierarki organisasi, melalui mana seseorang berpindah dalam tahapan karir yang diprediksikan. Menurut Hall seperti yang dikutip oleh Orpen (1994), mendefinisikan karir sebagai sejumlah pengalaman dan aktivitas kerja yang berpengaruh baik terhadap tujuan personal karyawan maupun tujuan organisasi, yang harus dijalani atau ditempuh oleh setiap orang selama kehidupan kerjanya, yang sebagian dibawah kendali personal dan sebagian lainnya dikendalikan oleh organisasi.

Berbagai literatur mengenai perilaku atau behavioral science, pada dasarnya mengemukakan tiga pengertian tentang karir (Handoko, 1999), yaitu:

(1) Karir sebagai sesuatu urutan promosi atau pemindahan secara lateral ke jabatan-jabatan yang lebih menuntut tanggung jawab atau lokasi-lokasi yang lebih baik dalam atau menyilang hirarki hubungan kerja selama kehidupan kerja seseorang.

(2) Karier sebagai penunjuk pekerjaan-pekerjaan yang membentuk suatu pola kemajuan yang sistematik dan jelas - jalur karier.

(3) Karier sebagai sejarah pekerjaan seseorang atau serangkaian posisi yang dipegangnya selama kehidupan kerja. Dalam konteks ini, semua orang dengan sejarah kerja mereka disebut mempunyai karier.

Pengelolaan karir secara efektif akan menyediakan suatu jalur karir yang menunjukkan pola pekerjaan yang berurutan dan membentuk karir individu karyawan. Sehingga untuk mencapai keberhasilan dan kesuksesan karir seperti yang diinginkan maka diperlukan suatu proses dan perencanaan karir . Keberhasilan karir individu karyawan merupakan hasil kerjasama dari usahausaha yang dilakukan karyawan dan organisasi, atau dengan kata lain terdapat tanggung jawab bersama dalam pengelolaan karir individu dalam organisasi (Beckhard, 2001). Menurut Slocum (1968) dalam Garavan (1996), terdapat dua pendekatan pengelolaan karir, pertama , pengelolaan karir dari perspektif individu yang memandang karir sebagai fungsi dari latar belakang kehidupan personal karyawan, pendidikan, kemampuan, pengalaman kerja, ambisi, waktu dan sebagainya.

Perspektif individu mengelola karir dengan mengasumsikan bahwa karyawan memiliki kemampuan untuk menilai dan merancang prospek karir mereka sendiri dalam organisasi secara akurat, sehingga mereka akan mampu mengoptimalkan investasi kapital sumberdaya manusia serta memiliki pengalaman yang baik dalam mengelola faktor-faktor yang mempengaruhi mobilitas karir mereka di masa mendatang. Kedua, pengelolaan karir dari perpektif organisasi yang mengkaitkan karir dengan permasalahan struktural organisasi dimana karir individu di dalam organisasi dipengaruhi oleh struktur pasar internal, vacancy chain maupun politik organisasi. Dalam hal ini organisasi diharapkan untuk fokus pada pengelolaan karir yang menitikberatkan pada perencanaan dan perancangan sistem karir, baik dalam bentuk program maupun kebijakan manajemen karir yang mendukung pencapaian karir karyawan. 


\section{HAMBATAN - HAMBATAN MOBILITAS KARIR DALAM KONTEKS INDIVIDU DAN ORGANISASI}

Karir merupakan sesuatu yang terjadi disetiap kehidupan kerja karyawan tetapi karir tidak dapat terjadi dengan sendirinya. Cara organisasi dikelola dan hubungannya dengan bagaimana karyawan diorganisasikan akan menentukan tipe dan ruang lingkup karir yang mungkin dimiliki individu. Prospek mobilitas karir tidak hanya tergantung pada kemampuan dan motivasi individu itu sendiri tetapi juga pada pekerjaan spesifik yang ada dan tersedia di pasar internal organisasi. Sehingga sejauh mana individu berhasil mencapai keberhasilan karirnya membutuhkan kerjasama pengelolaan karir yang efektif baik di tingkat individu maupun di tingkat organisasi.

Prospek dan mobilitas karir karyawan dalam organisasi dipengaruhi oleh beberapa faktor baik pada tingkatan individu maupun tingkatan organisasi. Menurut Garavan (1996), terdapat beberapa hambatan bagi mobilitas karir yang berasal dari lingkungan internal dan eksternal seperti misalnya:

(1) Semakin tingginya tuntutan akan kesesuaian antara kemampuan karyawan dan kebutuhan pekerjaan dalam organisasi.

(2) Tingginya kompleksitas tuntutan akan kemampuan beradaptasi pekerja terhadap aplikasi tehnologi baru.

(3) Tingginya tuntutan spesifikasi pendidikan dan permintaan akan pengetahuan serta keahlian tehnis yang harus dimiliki pekerja.

(4) Semakin terspesialisasinya pendidikan sehingga mengarah pada stratifikasi horisontal dalam organisasi dan membatasi mobilitas karir secara vertikal.

(5) Keterbatasan prospek karir dan keanekaragaman pengalaman kerja yang melibatkan pertumbuhan intelektual dan psikologikal karyawan dalam perjalanan karir.

(6) Kurangnya pengalaman terutama pengalaman yang spesifik sehingga akan mengurangi penawaran akan orang-orang yang memiliki pemahaman sepenuhnya tentang organisasi agar bisa menjadi pemimpin yang efektif.

(7) Ketidakmampuan organisasi memenuhi harapan promosi setiap karyawan, karena banyaknya hambatan yang muncul terhadap mobilitas karir organisasi.

Berbagai faktor penghambat mobilitas karir tersebut diatas dapat menjadi penghambat potensial jika praktisi maupun pengelola sumberdaya manusia organisasi tidak mampu mengintegrasikan perspektif individu dan perspektif organisasi dalam praktek pengelolaan karir karyawan. Kondisi tersebut akan memunculkan situasi yang bersifat dysfungsional dikarenakan individu dan organisasi memandang karir dengan perpektif yang berbeda.

Beberapa studi menunjukkan bahwa seringkali karyawan dan organisasi memandang permasalahan yang muncul dalam mobilitas karir dengan sudut pandang yang berbeda. Dari sudut pandang individu, seringkali karyawan memandang karir hanya dari ketersediaan peluang atau kesempatan untuk maju maupun adanya dampak dari keusangan keahlian tehnis, sementara dari perspektif organisasi, pengelolaan karir lebih menitik beratkan pada bagaimana suksesi manajerial bisa terlaksana secara efektif dan efisien. Yang selanjutnya organisasi berharap bahwa dalam pengembangan karir karyawan tersebut relevan dengan tujuan organisasi sehingga akan diperoleh kesesuaian yang baik antara tujuan karir karyawan dengan kebutuhan organisasi.

\subsection{Hambatan Mobilitas Karir dari Perspektif Individu}

Terdapat beberapa faktor baik yang bersifat faktor-faktor psikologis dan faktor-faktor lainnya yang menjadi penghambat potensial bagi permasalahan dan mobilitas karir karyawan, antara lain :

(1) Kelas sosial, dimana struktur sosial akan membentuk perkembangan sosial individu melalui pengembangan orientasi karir, konsep diri, minat dan nilai-nilai yang diyakini , ketersediaan peluang karir bagi individu, maupun pengaruh latar belakang keluarga 
terhadap pencapaian karir (Miller dan Form, 1982 yang diacu oleh oleh Sonnenfeld dan Kotter).

(2) Adanya pendidikan dan pelatihan profesional. Sicherman dan Galor (1987) mengemukakan bahwa human capital akan mempengaruhi mobilitas karir, dimana peluang promosi merupakan fungsi dari sekolah, kemampuan dan pengalaman kerja. Pekerja yang memiliki latar belakang pendidikan yang baik dan terlatih akan memulai karir pada jenjang pekerjaan di tingkatan yang lebih tinggi daripada pekerja dengan latar belakang pendidikan yang lebih rendah dan kurang terampil.

(3) Konsep diri karir internal, dimana karir internal merupakan karir yang mampu dicapai oleh individu sedangkan yang dimaksud karir eksternal merupakan posisi formal, status , hierarki jabatan, dan sebagainya. Karir internal merupakan hasil dari sosialisasi awal dan pengalaman yangdiperoleh di tempat kerja, sehingga karyawan belajar apa yang baik dan mampu memotivasi mereka sepanjang meniti karir di organisasi. Nilai-nilai sosial juga memberikan konstribusi pada proses pembentukan karir internal. Schein mengemukakan suatu model konseptual, yang membedakan pengembangan orientasi karir, dimana karir dipandang sebagai proses menemukan career anchor yang kemudian menjadi fokus yang memandu kehidupan karir karyawan, menciptakan image yang dibangun berdasarkan kebutuhan, motivasi, talenta dan nilai-nilai. Terdapat lima dimensi career anchor yaitu: technical function, managerial competence, creativity, security dan stability, otonomy dan independency.

(4) Pilihan karir. Holland (1996) seperti yang dikutip Garavan (1996) mengemukakan bahwa orang dengan perilaku tertentu akan memilih lingkungan kerja tertentu. Holland juga mengidentifikasikan tipe kepribadian yang compatible dengan lingkungan kerja tertentu. Orang akan sukses berkarir jika terdapat kesesuaian antara kepribadian individu dengan pekerjaan yang dipilih. Arnold mengemukakan orang dengan kepercayaan diri yang tinggi akan membuat keputusan karir yang lebih baik daripada orang dengan percaya diri yang rendah.

(5) Kebutuhan pertumbuhan yang rendah, dimana meskipun seseorang memiliki kemampuan untuk melakukan tugas pada tingkat tinggi, tetapi kurang bernilai jika tidak ada peningkatan rewards sesuai dengan peningkatan tanggung jawab.

(6) Self-imposed constraints. Temuan dari studi yang dilakukan oleh Dalton memperlihatkan adanya kecenderungan dari beberapa karyawan tidak memahami dengan baik konsekuensi dari kenaikan peluang promosi pada tahapan awal karirnya, sehingga muncul biaya yang hilang akibat tidak dikembangkannya keahlian yang bersifat tehnis maupun sosial diawal karir dan mengarah pada kemandegan karir dini.

(7) Pengaruh keluarga. Dimana kedekatan secara geografis dengan teman, saudara atau kerabat akan berdampak pada mobilitas karir. Banyak karyawan menolak kesempatan karir ataupun pekerjaan karena komitmennya dengan keluarga. Dan juga seringkali alasan-alasan yang dimunculkan tidak ada kaitannya dengan pekerjaan.

(8) Usia. Beberapa studi menunjukkan adanya hubungan yang negatif antara usia biologis dengan mobilitas karir. Dimana menurut Ornstein, terdapat pengaruh usia terhadap mobilitas karir yaitu:

(a) Mid life transition period (40-45 th), sesuai dengan Levinson's model of life development, yang konsisten memperlihatkan adanya kecenderungan keengganan karyawan pada usia tersebut untuk dipindahkan pekerjaan atau realokasi karena adanya hambatan dari keluarga.

(b) Tahap penurunan, yang dihubungkan dengan super's career development model, yang secara konsisten menggambarkan karir, dimana pada tahapan ini individu tidak menyukai realokasi kecuali sangat dibutuhkan atau dalam keadaan terpaksa. 
(9) Gender dan ras. Bagaimana diskriminasi rasial dan seksual, maupun perlakuan-perlakuan terhadap etnis minoritas akan mempengaruhi dinamika dan mobilitas karir terutama untuk pekerja minoritas seperti wanita dan anak-anak.

\subsection{Hambatan Mobilitas Karir dari Perspektif Organisasi}

Terdapat beberapa faktor yang menjadi penghambat potensial bagi permasalahan dan mobilitas karir karyawan dalam organisasi, antara lain:

(1) Internal labor Market, dimana mobilitas karir karyawan tergantung pada ada tidaknya kebijakan promosi dari atas dan apakah suatu pekerjaan ada dalam peningkatan jabatan atau tidak.

(2) Promosi. Lee (1985) mengemukakan bahwa formalitas kegiatan promosi akan menciptakan masalah bagi pihak yang dipromosikan maupun pihak yang mempromosikan yang disebabkan seringkali manajer yang bertindak sebagai promotor memiliki informasi yang terbatas dan relatif kurang tentang kemampuan dan kapabilitas karyawan yang sesungguhnya (Rosenbaum, 1987).

(3) Kriteria dan Metode Seleksi. Mobilitas karir akan terhambat jika terjadi ketidaksesuaian antara kemampuan karyawan dengan kemampuan yang dibutuhkan organisasi, sebagai akibat dari penggunaan kriteria dan metode seleksi yang tidak realistis.

(4) Extrinsic Rewards. Bentuk penghargaan akan menjadi penghambat jika tidak mampu menunjang prestasi kerja karyawan. Ketidakmampuan organisasi dalam menciptakan sistem penghargaan ekstrinsik yang tepat akan menghalangi karyawan untuk meningkatkan jabatannya dalam organisasi.

(5) Kompetisi internal. Merupakan kompetisi yang terjadi di sepanjang jalur karir karyawan, yang seringkali digambarkan sebagai sebuah pertandingan sehingga akan memunculkan "winner" dan "loser". Karyawan yang memiliki posisi sebagai winner selanjutnya akan terlihat sebagai orang-orang potensial bagi penugasan-penugasan yang mendukung pencapaian keberhasilan karir mereka di masa yang akan datang.

(6) Kelemahan sistem pengembangan karir organisasi. Nicholson dan Arnold mengidentifikasikan empat hambatan dalam sistem pengembangan karir, antara lain: munculnya hambatan karir dalam organisasi, pengembangan politik karir, pengembangan karir mekanistik dan ketidakacuhan pada kegiatan pengembangan karir.

(7) Teknologi organisasi. Macam tehnologi yang digunakan oleh organisasi maupun lingkungan teknologikal dapat secara signifikan mempengaruhi peluang karir karyawan dalam organisasi.

(8) Perencanaan sumberdaya manusia yang buruk. Ketidak efektifan dan ketidak akuratan perencanaan sumberdaya manusia akan menghasilkan overstaffing.

\section{PENGEMBANGAN KARIR DAN INTERVENSI PENGEMBANGAN KARIR}

Berbagai macam hambatan pengembangan karir yang berasal dari individu secara terus menerus diminimalisasi dengan melakukan perencanaan karir maupun perumusan tujuan karir yang wajar dan realistis. Hambatan karir lainnya yang berasal dari organisasi juga dapat dikurangi dengan aktivitas pengembangan karir yang dilakukan oleh organisasi secara sistematis dan terprogram (Siagian, 1997).

Perencanaan karir yang dirumuskan individu karyawan akan melibatkan berbagai keputusan yang diambil saat ini untuk hal-hal yang dikerjakan di masa yang akan datang sehingga individu perlu untuk menetapkan langkah-langkah spesifik untuk mewujudkan rencana karirnya. Beberapa studi sebelumnya menunjukkan pentingnya pembagian tanggung jawab dalam pengelolaan karir karyawan yaitu pihak karyawan dan pihak organisasi dalam mengintegrasikan tujuan karir individu dan tujuan organisasi. Sehingga pengelolaan karir yang dilakukan secara bersama-sama antara karyawan itu sendiri dan organisasi akan meningkatkan efektivitas 
pencapaian tujuan karir sehingga mampu meminimalisasi hambatan bagi mobilitas karir dalam organisasi.

Kegiatan pengembangan karir oleh organisasi merupakan salah satu kegiatan fungsional manajemen sumberdaya manusia untuk mengatasi berbagai permasalahan struktural yang menghambat mobilitas karir karyawan. Pengembangan karir dapat digambarkan sebagai suatu proses pencapaian tujuan karir individu dan organisasi, bisa dalam bentuk kegiatan penyediaan informasi bagi karyawan, bimbingan konseling dan konsultasi untuk membantu karyawan dalam mengidentifikasikan kemajuan karir dan kepuasan kerja, serta peningkatan produktivitas karyawan (Bernes dan Magnusson, 1996). Kegiatan pengembangan karir bertujuan untuk membantu karyawan dalam mengidentifikasikan dan memahami kebutuhan, kekuatan, perencanaan dan implementasi dari tujuan karir. Dari sudut pandang organisasi, pengembangan karir juga bermanfaat untuk menarik dan mempertahankan karyawan dengan kualitas yang excellent, mempertahankan dan meningkatkan motivasi kerja, loyalitas dan kepuasan kerja.

Menurut Siagian (1997) terdapat berbagai faktor-faktor fundamental untuk menunjang kegiatan pengembangan karir karyawan, antara lain:

(1) Prestasi kerja yang memuaskan yang selanjutnya dijadikan dasar bagi kegiatan penilaian dan promosi. Prestasi kerja yang bagus merupakan indikator bahwa karyawan memiliki potensi yang dapat dikembangkan dalam mempersiapkan pelaksanaan tugas dan tanggung jawab yang lebih besar di masa yang akan datang.

(2) Jaringan kerja dan kontak internal, yaitu pihak-pihak yang akan mempengaruhi dan mengambil keputusan mengenai kebijakan promosi dan penilaian prestasi kerja. Menjalin hubungan interpersonal baik dalam struktur organisasi formal maupun informal dengan pihakpihak pengambil kebijakan promosi dan penilaian akan dapat mempengaruhi mobilitas karir karayawan dalam organisasi.

(3) Loyalitas terhadap organisasi yang merupakan dedikasi jangka panjang karyawan terhadap organisasi, yang merupakan

(4) Pemanfaatan mentor dan sponsor. Keberhasilan karir karyawan dapat dicapai karyawan melalui bantuan dari mentor atau sponsor dalam bentuk pemberian informasi tentang kesempatan yang tersedia untuk dimanfaatkan seperti pendidikan tambahan, pelatihan , seminar dan sebagainya.

(5) Dukungan dari bawahan dalam pelaksanaan tugas akan sangat menentukan efektivitas karir atasan.

(6) Pemanfaatan kesempatan untuk tumbuh yang disediakan oleh organisasi seperti keikutsertaan dalam program pelatihan, melanjutkan pendidikan, program mutasi atau transfer dan sebagainya.

(7) Berhenti atas kemauan dan permintaan sendiri jika menghadapi stagnasi karir pada suatu organisasi dan meniti karir pada organisasi lain yang memiliki jalur dan pengembangan karir yang jelas sesuai tujuan karir karyawan.

Intervensi secara proaktif yang dilakukan oleh organisasi bertujuan untuk meminimalisasi hambatan mobilitas karir yang akan meningkatkan kesesuaian antara karyawan dan organisasi, menciptakan komunikasi yang lebih baik antara karyawan dan manajer serta peningkatan loyalitas karyawan kepada organisasi (Kirk dkk, 2000). Menurut Kirk dkk., terdapat berbagai bentuk kegiatan intervensi dalam pengembangan karir karyawan oleh organisasi sebagai berikut : 
Tabel 1. Intervensi Pengembangan Karir oleh Organisasi

\begin{tabular}{|c|c|c|}
\hline No & Intervensi & Deskripsi \\
\hline 1 & Jalur karir alternatif & $\begin{array}{l}\text { Menguji ketrampilan dan pengalaman untuk berpindah pada } \\
\text { jalur karir yang baru }\end{array}$ \\
\hline 2 & Pusat penilaian & $\begin{array}{l}\text { Aktivitas atau latihan yang digunakan untuk } \\
\text { mengidentifikasikan karyawan yang potensial }\end{array}$ \\
\hline 3 & Career coaching & Membantu karyawan dalam mepersiapkan perpindahan karir \\
\hline 4 & Cross pathing & Membuat perencanaan karir setiap karyawan \\
\hline 5 & Cross-training & $\begin{array}{l}\text { Mengajar karyawan beberapa ketrampilan untuk menjalankan } \\
\text { pekerjaan tertentu }\end{array}$ \\
\hline 6 & Dual career track & $\begin{array}{l}\text { Jalur karir yang menyediakan keberhasilan dan penghargaan } \\
\text { tanpa peningkatan jabatan }\end{array}$ \\
\hline 7 & Flexitime & $\begin{array}{l}\text { Memperbolehkan karyawan untuk bekerja dengan variasi } \\
\text { jadwal agar lebih cocok dengan kehidupan personal } \\
\text { karyawan }\end{array}$ \\
\hline 8 & Job enlargement & Meningkatkan jumlah pekerjaan karayawan \\
\hline 9 & Job enrichment & $\begin{array}{l}\text { Meningkatkan jumlah tanggung jawab dan pengendalian } \\
\text { karyawan pada posisinya }\end{array}$ \\
\hline 10 & Job rotation & $\begin{array}{l}\text { Memindahkan karyawan dari satu jabatan ke jabatan lain } \\
\text { dalam satu perusahaan }\end{array}$ \\
\hline 11 & Phased retirement & $\begin{array}{l}\text { Mengurangi skedul kerja dan tanggung jawab sampai } \\
\text { mencapai masa pensiun }\end{array}$ \\
\hline 12 & Job sharing & $\begin{array}{l}\text { Dua orang karyawan berbagi dalam full-time job termasuk } \\
\text { didalamnya jam, gaji dan tunjangan }\end{array}$ \\
\hline 13 & Sabbaticals & Memperpanjang masa kerja \\
\hline 14 & Penugasan sementara & Penugasan pada proyek khusus \\
\hline
\end{tabular}

Sumber tabel dari : Kirk, James et.al, (2000), hal. 206

Berbagai bentuk intervensi pengembangan karir membutuhkan dukungan baik dari pihak karyawan maupun organisasi melalui berbagai program personalia. Terdapat paling sedikit lima manfaat sistem pengembangan karir yang baik bagi organisasi, antara lain:

(1) manajemen pengembangan karir akan membantu karyawan dalam pengembangan karir yang akan meningkatkan loyalitas.

(2) ketersediaan kelompok karayawan dengan potensi dan kemampuan untuk mengisi lowongan jabatan di masa yang akan datang.

(3) membantu mentor dan sponsor dalam mengidentifikasikan kebutuhan karyawan dalam kegiatan pelatihan dan pengembangan.

(4) memperbaiki prestasi kerja, peningkatan loyalitas, motivasi dan kepuasan kerja.

(5) meningkatkan produktivitas dan kemampuan kerja karyawan.

\section{PENUTUP}

Karir merupakan sesuatu yang terjadi di setiap kehidupan kerja karyawan, tetapi karir tidak dapat terjadi dengan sendirinya. Untuk mewujudkan keberhasilan karir seperti yang diinginkan karyawan dibutuhkan upaya-upaya serius dalam pengelolaannya baik yang dilakukan oleh karyawan itu sendiri maupun organisasi.

Aktivitas pengelolaan karir yang dilakukan oleh karyawan dalam bentuk perencanaan karir, penetapan tujuan dan sasaran karir serta penetapan jalur karir. Pengelolaan karir oleh organisasi dilakukan melalui berbagai aktivitas pengembangan karir yang bertujuan untuk 
membantu karyawan dalam mengidentifikasikan peluang kemajuan, peningkatan kepuasan kerja dan peningkatan produktivitas karyawan (Bernes dan Magnusson, 1996).

Pengembangan karir seharusnya tidak hanya disandarkan pada usaha individual karayawan saja, tetapi juga harus didukung pengelolaan karir oleh organisasi dalam bentuk penyediaan sistem pengembangan karir .Berbagai hambatan dalam mobilitas karir berusaha diminimalisasi dengan mengembangkan berbagai bentuk intervensi pengembangan karir .

Aktivitas pengembangan karir yang dilakukan organisasi dapat membantu karyawan untuk mengidentifikasikan dan memahami kepentingan, kekuatan, perencanaan dan pengimplemtasian tujuan-tujuan karirnya secara jelas. Pengembangan karir juga dapat membantu perusahaan untuk menarik calon karyawan dengan kapabilitas tinggi, memotivasi, mengembangkan dan mempertahankan karyawan terbaik sepanjang waktu. System pengembangan karir yang baik akan meningkatkan kesesuaian karyawan - organisasi dengan lebih baik, komunikasi karyawan dengan manajer akan lebih baik, dan juga meningkatkan loyalitas karyawan terhadap organisasi (Kirk dkk, 2000).

\section{DAFTAR PUSTAKA}

Belcourt,M dan P.C. Wright, (1994), "A Management Development : A Career Management Perspective", The International Journal of Career Management, Vol.6. No.5, pp 3-10.

Garavan, Thomas N. (1996). "Career mobility in organizations: implications for career development- part 1". Journal of European Industrial Training. Vol. 20 No. 4 pp. $30-40$.

Garavan, Thomas N. (1996). "Career mobility in organizations: implications for career development- part 2". Journal of European Industrial Training. Vol. 30 No. 5 pp. $31-39$.

Havaleschka, F., (1996), "Personality and Leadership: a benchmark study of success and failure", Leadership \& Organization Development Journal, Vol.20.No.3, pp.114-132

Holland, J.L. (1996). The Psychology of Vocational Choice. Blashdel, Waltham, MA.

Kirk, J.F et.al, (2000), "Name your career development intervention", Journal of Workplace learning, Vol.12 No.5, 2000, pp.205-216

Kirk, P dan Broussine,(2000), "The politics of facilitation", Journal of Workplace Learning, Vol.12. No.1., pp. 13-22

Lee, R. (1995). "The theory and practice of promotion processes: part one". Leadership \& Organization Development Journal. Vol.6 No.2 1995 pp.3-6.

Lee, R. (1995). "The teory and practice of promotion processes: part two". Leadership \& Organization Development Journal. Vol.6 No.4 1995 pp.17-21.

Rosenbaum, J.E. (1987). Career Mobility in a Corporate Hierarchy. Academic Press, New York, NY.

Siagian, Sondang P. (1996). Manajemen Sumber Daya Manusia. Bumi Aksara, Edisi 1, Cetakan 5.

Sicherman, N dan O. Galor. (1987). "A theory of career mobility". Journal of Political Economy. Vol.98 No.11 1987 pp.15-23.

Sonnefeld,J. dan J.P. Kotter. (1982). "The maturation of career theory". Human Relations. Vol.35 No.1 1982 pp. 19-46. 